\title{
Permanent Grant of Land Certificate for Adat People, is it Possible?
}

\author{
Yusuf Saepul Zamil”, Supraba Sekarwati, Yani Pujiwati and Ida Nurlinda
}

Faculty of Law Padjadjaran University, Sumedang 45363, Indonesia

\begin{abstract}
Adat peoples mean the original inhabitants or the first inhabitants of a country or the earliest population's descendants lived in the area. All this time, adat people in Indonesia have always been marginalized and banished from their homeland. Companies that acquired investment permits from the government often dismiss the adat peoples for their interests. This dismissal occurs due to the absence of proof for the collective land ownership (ulayat land), which is used and utilized collectively and communally. This article discusses the possibility of permanently grant the land certificates to provide legal protection for the adat peoples. Granting a certificate of land rights is possible if the government changes the land registration system from the negative to the positive system (torrens system). Adat peoples may acquire land certificates if they are considered as a legal entity. According to Indonesian law, only individuals or legal entities can register ownership of land. To make adat people a legal entity is by making regulations by the Minister of Agrarian and Spatial Planning which states that adat people in certain areas who have met the requirements are declared as legal entities.
\end{abstract}

Keywords: Registration, land, permanent, peoples, adat.

\section{INTRODUCTION}

Investments must protect the local cultures' values (Kawharu, 2015) and added-value to the people's prosperity (Watson, 1996), instead of destroying them. For this purpose, investment requires a permit as a government's instrument to conduct supervision over the investment activities. However, there has been an abuse of permit's conferment practice where many have damaged people's life structure.

It frequently injures the adat peoples, many ulayat lands supposedly owned by adat peoples overlapped with the land ownership given to the companies through their investment permits. It inflicts prolonged conflict between the two, and it is difficult to resolve such matters.

Adat peoples mean the original inhabitants or the first inhabitants of a country or a country's specific territory at the time of conquest, colonialism, or the current determination of a country's boundaries (Hindeya, 2019). The first definition of adat peoples refers back to the original definition submitted at the World Council on Adat peoples in 1975, describing the earliest population's descendants lived in the area. However, in 1984 the same organization offered the second definition referring to the earliest descendants of the people inhabiting the area before colonialism (Waldron, 2003).

*Address correspondence to this author at the Faculty of Law Padjadjaran University, Sumedang 45363, Indonesia; Tel: +622284288827;

E-mail: yusuf@unpad.ac.id
However, even though they are natives of a country, their existence is often marginalized by immigrant communities and marginalized by the country's regulations.

Indonesia is a country that consists of various adat peoples' tribes that have their every territory, consisting of housings, plantations, forests, and coastal areas. These portions of lands under the authority of the adat peoples are commonly known as the ulayat land.

It is getting easier for the adat peoples to lose their rights upon the ulayat land due to the increasing grant of various rights. On the other hand, acquiring ulayat land is getting more complicated by days due to 2 (two) factors. First, the internal factor, more and more adat peoples are migrating to the urban areas; they no longer pay attention to the ulayat land's existence. From the legal perspective, this has consequently changed the status of the land into the country's proprietary.

Second, the external factor, an increasing number of companies are trying to take the ulayat land, either through legal or illegal manner. Legally, they seek business permits from the government to do business above the ulayat land, and illegally, they forcefully confiscate the land without the government's permission. Despite being conducted legally, ulayat land acquisition has violated the sense of justice among the adat peoples. The government should have protected adat peoples' interest instead of taking part in ulayat land takeover by other parties. If not towards the country, then who should the adat peoples ask for legal protection. 
The adat peoples are generally controlling the forests, plantations, lakes, and coastal areas. Unfortunately, they often have to admit defeat and leave these places for companies' and country's interests. Legal permits from the government work as support for these companies to use the lands. Some of the permits include mining permits, plantation permits, coastal area management permits, forest clearing permits, industrial permits, housing permits, tourism permits, and various other permits.

Law enforcement officers who are supposed to protect the adat peoples tend to help companies' interests so far they can show the business permits as the proof of permission from the country. Meanwhile, the adat people cannot stand for their rights over the ulayat lands since they do not have any ownership evidence. Nonetheless, even without any proof of ownership, it is unjustifiable for other parties to chase them out as it has been happening. The country itself is obliged to protect adat peoples' ownership over the ulayat land as regulated under Article $28 \mathrm{H}$ paragraph (4) of the 1945 Constitution, which stated that every person is entitled to have the right of ownership, no person shall be permitted to take it arbitrarily. It is a given that when a personal proprietary is prohibited from arbitrary takeover, the same must have applied to the collective ownership, such as the communal land.

Obvious legal protection for adat peoples in this regard may be through the land registration system. It will provide both justice and legal certainty to them over their ulayat land.

This paper discusses ways to provide legal protection for adat peoples towards their ulayat rights, whether it is possible for the adat peoples to obtain permanent certificates over the land rights through the positive land registration system (torrens system).

\section{METHODOLOGY}

This study used the normative-juridical method by taking secondary data as the primary research materials; the practice is elaborated in a descriptiveanalytical manner by describing the relationship between the adat peoples in Indonesia and their ulayat rights, as well as comparison of adat peoples in several countries. The analysis was made through a qualitative approach conducted towards the research results, to answer the problems arising from this study, with the expectation that the government may use them as the basis of creating policies and role models in providing legal protection for adat peoples in Indonesia and may inspire the same for several other countries, particularly concerning the legal certainty of the land ownership for the adat peoples.

\section{DISCUSSION}

\section{The Regulation Governing the Adat Peoples in Indonesia}

Indonesia recognizes the rights over ulayat land in the Article 18B paragraph (2) of the 1945 Constitution, "the State recognizes and respects the unity of adat peoples and their traditional rights as long as they live and it is following the social development and the principles of the Unitary State of the Republic of Indonesia as regulated under the Laws." Then, the Article 28I paragraph (3) of the 1945 Constitution stated that "respect towards the cultural identities and rights of the traditional peoples must be preserved following the times and civilizations."

The recognition towards the ulayat land is elaborated both under the constitution and its derivative laws, for instance, in Article 3 of Law No. 5 of 1960 concerning the Basic Agrarian Principles (Peraturan Dasar Pokok-Pokok Agraria/UUPA). It is stated that "as long as it exists, the implementation of the ulayat rights and such other similar adat rights, must be made in such a way in line with the nation's and the country's interests, which is based on the national unity and must not in contrary with the Laws and other higher regulations."

Even though the State recognizes the existence of ulayat land in the existing regulations, many government policies, in reality, dismissed the adat peoples from their ulayat lands. Many permits to conduct businesses were issued over the ulayat lands; it causes overlapping ownership within the same land and leads to land ownership loss for the adat peoples.

Generally, in Indonesia, a land under the adat group's ownership is called an ulayat land; despite its different designation from one place to another, it is communal and not personal.

According to the Article 1 number (1) of the Regulation of the Minister of Agrarian Affairs/Head of the National Land Agency No. 5 of 1999 concerning the Guidelines for the Dispute Settlement for Adat Peoples' Ulayat Rights, the Ulayat Rights and its likelihood attached to the adat peoples is the authority under the adat law owned by the adat peoples over a specific 
part of areas, where the inhabitants may obtain benefits from natural resources, including the land, in such area, for their life and livelihood, arising from a hereditary and unbreakable physical and spiritual relationship between the adat peoples and the land in concern.

\section{The Existence of Adat Peoples in Indonesia}

Article 2 paragraph (2) of the Regulation of the Minister of Agrarian Affairs/Head of the National Land Agency No. 5 of 1999 concerning the Guidelines for the Dispute Settlement for Adat Peoples' Ulayat Rights indicates the existence of the adat peoples in case of:

1. Presence of a group of people who still value the boundaries with the adat law system as the common inhabitants of a legal alliance, as well as recognize and implement the provisions applicable in such legal alliance in their daily lives;

2. Presence of ulayat land where the inhabitants of such legal alliance may seek a daily livelihood in that land; and

3. Presence of adat law system regarding the management, control, and use of the ulayat land applicable and complied by the legal alliance's inhabitants.

Thus, in conclusion, ulayat land's existence relies on the presence of adat peoples and adat administrators permanently residing on the part of the land and equipped with the adat chief or committee along with a recognized and complied adat laws among the adat peoples.

One of the examples of the existing adat peoples is the Baduy tribe in Lebak Regency. They are now facing problems concerning land shortages; their population is increasing, yet the ulayat land in their authority remains the same. They hope for the government to grant an additional portion of lands they can use collectively (Rifa'i, 2020).

The government has recognized the existence of the Baduy tribe through the Regional Regulation of the Lebak Regency No. 32 of 2001 concerning the Protection of the Baduy Peoples' Ulayat Rights. Article 2 of the regulation governs that the Baduy tribe has an Ulayat Right over a limited portion of lands in the Kanekes Village Area, Leuwidamar Sub-District, Lebak Reg. The boundaries are measured according to the reconstruction map and outlined in a Minutes as the basis of the Regent's decision. The regulation also affirms that the Baduy tribe holds full control over the ulayat land utilization and management; for this matter, they must be considered having great luck. Many tribes in Indonesia have not received the same recognition either for their ulayat land or their territory.

The Baduy tribe is known for its wisdom in managing the natural resources; they divide the adat territory into three areas, namely leuweung tutupan, leuweung titipan, and leuweung awisan. Leuweung tutupan is a forbidden forest area, leuweung titipan is a forest area only accessible for certain people such as the adat elders for specific purposes, for example, for the traditional ceremonies, and the leuweung awisan is a jointly managed area for the agricultural, housing, plantation and other purposes to support the society's life (Dalidjo, 2020).

Besides the Baduy tribe, the government also recognizes the Minangkabau tribe's ulayat land in West Sumatra through the Regional Regulation of the West Sumatra Province No. 16 of 2008 Ulayat Land and its Utilization. However, despite this regional regulation, there are no specific boundaries described to designate the area or the ulayat land. The regulation is generally applied to one province since, in that province, the ulayat lands and the adat peoples are scattered in several areas. It is hard to determine boundaries for such conditions.

This regional regulation has a weakness; its Article 8 letter b stated that the customary chief might register the ownership over the ulayat land under his name. Iy violates the communal concept of the ulayat land, where it is supposed to have no owner even in the case of a customary chief. Consequently, at the time of the chief's death, the ulayat land will be considered as an inheritance proprietary, despite that the land is supposed to be jointly owned by the adat peoples.

Other adat peoples that still exist in Indonesia are the Dayak tribes. The Dayak Kenyah tribe of East Kalimantan mostly resides in the Jelarai Village. This area is relatively large and consists of protected forests and people's forests. Their main source of livelihood system is agriculture based on the living regulation adhered to by the society, including the regulations related to the control and use of the ulayat land (Susyanthi, 2020).

For the people in Papua, including the Asmat tribe, their relationship with the ulayat land is not merely 
providing them with food as the economic fulfillment; it signifies the historical and sacred values of the relationship. In other words, the relationship cannot be viewed as a unilateral connection between humans from t homo economicus perspective; it must also be seen from homo humanicus and homo culturalis point of views, it means aside from the external connection, the land shall also have an internal and sacred relationship with human's spirit (Deda, \& Mofu, 2014).

North Sumatra province still has the Batak tribe; their ulayat lands are called huta, lomban, and bius. Huta is the smallest in size; several families usually inhabit it under one clan. The combination of several hutas with the same interest is called lumban and horja; meanwhile, bius is the largest unit consisting of several lumbans or horjas.

The right to manage adat territories in Maluku is called petuanan; it extends from the land to marine areas. Under this right, there are other rights in which utilization and management are governed according to the adat rules (Tamagola, 2020).

According to the Alliance of the Adat Peoples in the Archipelago (Aliansi Masyarakat Adat Nusantara/AMAN), Indonesia is the home to 2359 adat tribes attached to their respective ulayat lands with 17 million registered the AMAN members. Nonetheless, the Indonesian government does not officially recognize such data, since it has no official body or institution that has the task to update the data, or take care and protect the adat peoples ulayat lands.

As of the date of independence, Indonesia has never officially recorded the number of adat peoples or existing ulayat rights. The government has not even collected the adat peoples' data formally, let alone recognizing the adat peoples' rights over the ulayat lands or territories.

\section{Several Examples of the Ulayat Land Disputes in Indonesia}

Ulayat land disputes have occurred in several areas in Indonesia. One example was in West Sumatra, where the dispute arose when there was a seize of Nagari land conducted by a plantation company; it controlled a portion of land by illegally converting the forest into a plantation exceeding the boundaries defined in the permit granted by the government (Kurniawan, 2020). Likewise, in the case of adat peoples of Megow Tulang Bawang in Lampung, their ulayat land was controlled by a plantation company without any apparent underlying rights (Sukoyo, 2020). It is permissible for other parties such as plantation or forest product management companies to administer an ulayat land; however, such other parties must obtain permits from the country, customary chief, and the adat peoples. They must also pay incentives to the adat peoples and employ them as workers to increase their welfare.

In Mesuji, Lampung, there was a land seizure case involving the adat peoples, encroachers, and plantation companies. The confusion started when the adat peoples claimed ownership upon a land registered under a plantation company's business permit; the gravity of the situation escalated when the encroachers kept on coming to the land. The land itself is registered under certificate number 45 (as a country's forest), and countless lives have been falling within such conflict (Yasand, \& Firmansyah, 2020) ever since 2000. Notable incidents resulted in many deaths that occurred in 2001, 2009, 2011, and recently in 2019. The source of the disputes was from a land dispute where the government frequently ignore the adat people's ownership over lands and granted numerous concessions for the forest's management to many companies; this has, in turn, cause conflict between the companies with the adat peoples. The complexity of the problem increased when encroachers tried to open agricultural land within the forest and establish permanent buildings (Permana, 2020).

Another dispute involving the adat peoples also occurred in Papua, where 52 hectares of their ulayat lands were seized for Sentani Airport's construction without compensation (Hidayat, 2020). The government was faced with a dilemma in this regard since compensation upon seizure needs proof of land ownership, such as a land certificate. However, it is a given that the adat peoples do not have written evidence over the ulayat land. In case the government provides compensation without basis, then the official held responsible for this matter shall be subjected to legal issues by causing loss to the country.

Still, the said reasoning certainly unacceptable to justify the government's actions in refraining from providing compensation. The adat peoples are affected by the government's decision to use the ulayat land to procure the public interest. The physical control of the land should have been sufficient to prove the people's land ownership as the basis to provide compensation.

The government must provide compensation in the event of seizure of the adat people's land; if not, it 
should be considered a violation of human rights. The same should have applied to the forced expulsion. The most ideal form of compensation for the adat peoples in this sense is money and substitution of land. However, suppose it is impossible to provide both. In that case, the latter must be preferable since the adat peoples have a tight connection with the land as the place to live and make an economic livelihood.

The adat peoples of the Anak Dalam tribe in Batanghari Regency, Jambi Province, also encountered disputes concerning their ulayat lands. They claimed that a plantation company took over their lands, covering an area of 2,053 hectares. The Anak Dalam tribe received their ulayat land from their ancestor, in; ins case they were offered a partnership with a plantation company to hand over their lands for a palm-oil plantation. The company promised to divide the benefit by $70 \%$ and $30 \%$ between the adat peoples and the plantation company. It is unfortunate that after releasing their land, the Anak Dalam tribe neither got the compensation nor benefit they should have received as promised (Ramadhani, 2020).

It is common for the adat peoples to be tempted with compensation or an offer to become plasma farmers by the plantation companies in exchange for handing over their lands. The adat peoples were often faced with no choice other than yielding due to the plantation company's more vital position. Not only that, the company has already had the business permit for plantation; it also has the Right to Cultivate certificates from the government. As happened to the Anak Dalam tribe, the adat people's compensation rights are rarely materialized after the land handover has been made.

One of the most significant problems for ulayat las the nationalization. During the colonial period, many colonial companies seized or leased the ulayat land. After independence, the country took over the ownership of such lands through nationalization and grant access for the state-owned company to create plantations, while it should have been restored to the adat peoples.

Such a case also occurred to the ulayat lands in the Deli Kingdom, at the time of nationalization of the ulayat land,s which was previously leased by a Dutchowned plantation company. The government only provided compensation to the Dutch company and did not give any for the adat peoples even when both the assets and the lands had been taken over (Daulay, 2020). Despite that, there was a rent agreement between the Dutch company and the Deli Kingdom (Vadilla, 2020) the government handed over the management of such ulayat lands to the national plantation company (Perusahaan Perkebunan Nasiona/PTPN). In the absence of compensation, the government should have returned the ulayat lands to the possession of the adat peoples of the Deli Kingdom as a nationalized asset.

The conflict arose between adat peoples and the country and between the adat peoples and the companies or capital owners often caused by a different interpretation of the country's land. In Indonesia, the country's land consists of 2 (two) categories: the country's open land and the country's closed land. There are no other rights attached to the country's open land; while there is for the country's closed land, the two usually have either public or private character. The public rights are attached over the government institution's land, while the private rights are attached to the civil land, such as the right of ownership, the right to use, and the right to cultivate.

According to the country's interpretation, the ulayat land is under the category of the country's open land, authorizing the country to freely issue any underlying rights over it, such as the right to cultivate along with the plantation permit for the plantation companies. Meanwhile, the adat peoples consider that the ulayat land is a country's closed land; it means that the government is unauthorized to issue rights over the ulayat land. However, the country still issues other rights granted to other parties over the ulayat lands in reality.

The country claims and declares that all Indonesia's forests are owned by the country, while the adat peoples contested that the adat peoples own some of the forests. Thus, they claim that the government must refrain from acting freely to the adat peoples' forests.

\section{The Importance of Adat Peoples' Presence in a Country}

Many countries have told similar tragic histories of forced assimilation and seizure of lands towards the adat peoples. While the European societies were achieving their political independence against colonial power, the former colonies' adat peoples remained targeted for discrimination and land seizure. Since the adat peoples do not own the evidence of the land rights in a recognized manner for the European law system, it is easy to severe their ties with their ancestral 
territories and make way for the colonial landowners (Pereira, \& Gough, 2013).

The adat peoples have been suffering from a tragic fate under 2 (two) kinds of oppressions, the first was during the colonial occupancy, and the second is after the independence up to this date. In the past, the colonialists forcibly confiscated the adat peoples' land, while on the current date, they were forced to prove their land ownership. It is difficult for the adat peoples to verify their rights over their lands since the existing land system in their country is still adopting the colonial law; they must register the land by submitting written evidence.

The adat peoples cannot prove their land ownership due to the absence of this written evidence in their possession. The adopted land system from the colonial era does not accommodate the land ownership for the adat peoples, to begin with. As if trying to reap benefits from this condition, many parties with interests seemed to seize the opportunity to take over the adat peoples' lands. Even though the further study may signify the significance of the adat peoples and their lands for a country or even for the world.

Most adat peoples seek livelihood through farming; therefore, access to the lands is vital for their daily needs. Agriculture contributes to the protection of food security within a country; consequently, access to the lands may exterminate the world's famine issues (Nyarko, 2019). Closing access for the adat peoples to the lands is hardly equal to increasing the world's poverty rate. This often occurs in several countries, including in Solomon Island, where companies proceeded with logging over the adat peoples' land (Forrest, \& Corrin, 2013).

The practice of logging in Indonesia was usually accompanied by security forces and left the adat peoples powerless. However, since the companies conducting the logging have obtained the government's logging permit, it is natural for the security forces to guard the logging act willingly.

Unfortunately, companies frequently cut the trees which are under the protection and preservation of the cultural heritage. It shows that in addition to depriving the economic resources for the adat peoples, logging has also eliminated the cultural heritage of a country.

For adat peoples worldwide, sacred sites and other traditional cultural properties are significant for preserving their culture. Often, a sacred site is a part of natural landscapes and is usually integrated into the mineral resources either in part or whole. It may also be formed from the project locus to develop extractive industries and other industries aimed to remove or process the oils, gases, coals, and minerals. Historically, many businesses tend to resume development projects without considering the importance of the sacred sites in influencing the adat peoples and, consequently, causing irreparable damage.

However, in recent years, there has been recognized to the rights of the adat peoples to access, use and protect their sacred sites under international law, including the United Nations Declaration on the Rights of Adat Peoples, and the domestic law applied in the countries around the world. Several sources of international law, including the ones related to the industrial standards, suggest or compel the states and business entities, either companies or multinational companies, to consult or obtain consent from the most likely affected adat peoples before the commencement of and during the development of projects on a sacred site (Butzier, \& Stevenson, 2014).

The country should have involved the adat peoples in creating each of the affecting policy, and refrain from making a unilateral decision. As mandated by the United Nations Educational, Scientific, and Cultural Organization (UNESCO), the adat peoples are one of the local cultural heritage of a country that must be protected.

Nevertheless, the adat peoples have given many contributions to the country development, including in Indonesia. It shall be better for the government to refrain from underestimating their presence. An example of their contribution is when they concoct herbal plants for pharmaceutical use in the health sector to heal the world (Nijar, 2013).

Herbal plants mostly grow on the ulayat lands; therefore, such carefully managed plants shall be displaced in case of eviction. This is, in fact, very detrimental to the country's development or even to the world. Apart from the health sector, adat peoples also contribute to food, clothing, and others.

As happened in Indonesia, adat peoples' protection in Africa is regulated under each State's constitution. However, its real practice is very disappointing; the states use various excuses to confiscate the adat peoples' ulayat lands (Wily, 2018). 
Adat people's way of life and livelihood must be protected as the legacy of a country. West Australia has a specific regulation called the Aboriginal Heritage Act 1972 to protect the Aboriginal people as its cultural heritage (Treasure, 2016).

Most of the adat peoples in Indonesia and Malaysia are permanent residents, and a few others are nomadic. Some of the nomadic peoples in Malaysia are continuously changing residence for years, except for the Batek Kelantang and Pahang in the Malaysian Peninsula and the Penan in Sarawak, which is still living the semi-nomadic life (Azmi, 2017). The expulsion of the adat peoples from their permanent residence for years will leave them with no other place to go; there is no guarantee that they will get a replacement for their source of life.

Customary law in Australia is unwritten, just as it is in Indonesia (Corrin, 2014). Land ownership for the adat peoples is also made through the unwritten regulations. The adat peoples have spiritual values and a special relationship with their lands (Gunn, 2013). Their sacred and strong relationship with the lands is inherited from their ancestors. They do not treat the lands as an economic commodity that can be sold when the value is promising. They refuse to sell their lands at any price on the ground that they must always protect and pass on their ancestral lands to the next generation. Thus, forceful eviction will inflict painful injury to the adat peoples.

Adat peoples have existed even before the formation of a country. Usually, a state is established since its independence day, freed from colonialism or obtaining other countries' recognition. Thousands of years before the country's formation, there have been living the adat peoples indigenous to the area. Unfortunately, they are often placed in a disadvantageous position by the State's law. The Aborigines in Australia, for example, have struggled their part to acquire recognition from the State towards the specific regulation of their own concerning the Aboriginal people as national law (Mclachlan, 1988).

Adat peoples' life is a part of the culture. In contrast, the culture itself is a form of human rights (Grant, 2006). This matter is regulated under Article 22 of the Universal Declaration of Human Rights, which stated that "Everyone, as a member of society, is entitled to realize the economic, social and cultural rights indispensable for his dignity and the free development of his personality." The current international human rights law now provides some protections towards the rights of and the compensation of unlawful confiscation upon the adat peoples' lands (Charters, 2008).

The government should have invited the adat peoples into a dialogue on various public policies that will likely affect them (Eluyode, 2015) if such public policies affect the adat peoples' control and ownership of their lands.

In many parts of Africa, the adat peoples are forced to get out of their ancestral lands to make room to establish nature conservation, tourism resorts, or natural resources extraction (Gilbert, 2017). Similarly, in Indonesia, the same occurred when mining materials are found in the ulayat land's perimeter.

A mutually beneficial scheme is necessary to maintain peace between the State or the parties that will manage the natural resources and the adat peoples. The State must learn to manage the natural resources without casting out the adat peoples from their lands. One of the schemes that may be suggested in this regard is the production sharing agreement for the natural produces resulted from the lands between the State as the management institution and the adat peoples as the landowner after deducted by the production costs. Nigeria is currently developing the laws and practices of public participation as the instrument to achieve successful minerals and natural resources development, free from conflicts and sustainable for the country's mutual benefit and the adat peoples (Kalu, 2008).

\section{Grant of Permanent Certificate to the Adat Peoples}

The customary law holds the original form of law in a country, however, in reality, the colonial law prevails over it (Akuffo, 2009). Land registration is a model brought about by colonialism. This system is unknown before the colonial era, yet the adat peoples were able to live peacefully side by side since they can respect their land ownership.

However, the condition is now different; it is mandatory for each citizen, including the adat peoples, to register their lands. Therefore, the adat peoples must be willing to register their lands to guarantee legal certainty.

One of the most crucial problems the adat peoples face is the absence of clear boundaries for the communal land. They usually use natural indicators as land boundaries, such as rivers, trees, cliffs, valleys, 
trees, hills, and other natural signs; this makes it hard to recognize the boundaries in the event of natural disasters or other events causing the natural indicators to disappear. Thus, it is common for other parties, such as the companies, to take over the lands either in part or whole. In case of protest, the adat peoples are usually losing since they cannot prove their ownership over the lands. On the other hand, companies have land certificates and management permits from the government.

The government might conduct a concrete effort to protect the adat peoples by issuing the land certificates for ulayat rights. This scheme has been accommodated on the Article 4 paragraph (1) of the UUPA, which stated that the State's right to control is underlying the determination of various rights granted upon the surface of the earth called as the land, it can be given to and owned by persons either individually or jointly with other people as well as by legal entities.

According to such an article, it is legally possible for the government to issue certificates to affirm ulayat rights. However, so far, the government has only been issuing certificates to persons (individuals) or legal entities to enact UUPA in 1960. There is a minimal case of certificate granted to several persons or a group of people, while none has ever been issued upon the adat peoples' ulayat rights.

The government begins to open the possibility to grant land certificates to a group of people through the Circular Letter of the Minister of Agraria and Spatial Planning/National Land Agency (ATR/BPN) Number 2/SE-HT.02.01/VI 2019 concerning the Grant of Right to Use Building for Limited Partnership (CV). A limited partnership (CV) is a non-legal business entity; it is different from the Limited Liability Company (PT); however, both must be established with a minimum of 2 (two) founders or more. As such, the government once issued a certificate under the name of several heads of business entities in the form of a limited partnership (CV).

Aside from the mentioned above, the government took a step forward by issuing the Decision of the Minister of Agraria and Spatial Planning/Head of the National Land Agency No.276/KEP-19.2/X/2017 concerning the Appointment of Pakraman Villages in Bali Province as the Subjects to Collective Ownership (Communal) Rights. According to the regulation under the Decision of the Minister of Agraria and Spatial Planning/Head of the National Land, the Head of the
National Land Agency can register the ulayat rights under adat peoples' names in the Pakraman Village (Sudantra, 2018). Thus, apart from individuals and legal entities, the government may also grant land certificates to the group of society. Pakraman village is inhabited by the adat peoples; it is not an ordinary village obliged to deliver governmental functions. It has inherited the unity of tradition and social manners from generation to generation. Unlike the ordinary village, Pakraman is not a legal entity; the grant of the land certificates to the group of peoples in Pakraman signifies the government's open attitude towards the concept of issuing certificates to the adat peoples.

The traditional village of Pakraman in Bali consisted of ulayat lands jointly owned in a communal manner by a group of people. The registration of ulayat land and issuance of the land certificate under the name of the adat peoples in Pakraman Village has shown tremendous progress in Indonesian land Laws. Unfortunately, this ministerial regulation is being specific in designating the adat peoples of Pakraman and may only be applied to that particular ulayat land in Bali, it does not apply to other ulayat lands in other areas in Indonesia. Nonetheless, adding up to the regulation in Article 4 paragraph (1) UUPA, these changes, of course in the governmental policies have opened up opportunities for a group of people to be considered as a subject of rights in land registration, or in short, the subjects are not limited only for the individuals or legal entities. Several examples of land registration under the name of a group of people show hope for a greater possibility that ulayat lands might be registered under the name of the adat peoples in concern.

The next question would be: how is the implementation of ulayat land registration? Is it possible to grant a permanent certificate to the adat peoples? The author views that the ulayat land registration might be executed generally as the applicable ordinary land registration system in Indonesia. The registration will use the negative system with positive potential. A land certificate does not apply absolutely. It means that the certificate is still-revocable by a court decision, in case of a claim proving otherwise. The the Indonesian government is currently reviewing the implementation of the positive land registration system (torrens system), where a land registration made in a certificate shall be absolute and permanent, without the possibility of cancellation due to the claim from other parties. In case this system is applied, the adat peoples can obtain a permanent land certificate. 
By issuing a permanent land certificate, the adat peoples will receive maximum legal protection, since it shall not be easily canceled. The only matter that may impair their rights in this regard is the possibility of land procurement necessity for the public interest. Then again, this applied to all types of lands; if the State needs land for development for the public interest, land rights release is mandatory, including the proprietary rights; the government will provide compensation accordingly.

A permanent certificate will prevent other parties in need of the lands, in this regard, the companies, to evict the adat peoples arbitrarily. It is also impossible for the State to issue business permits over the adat peoples' lands. If companies wish to utilize the ulayat lands, they need to submit for a lend-use scheme and pay royalties to the adat peoples, of course, upon their consent.

All this time, the national law has been handing over adat peoples' protection under the regional regulations. This means that the regional governments must recognize some areas' ulayat/communal status in the regional regulations to ensure protection. However, such recognition has a weakness; initiative for ulayat lands recognition lies under the respective regional governments' policies. In case the regional government is reluctant in issuing the regional regulation, then the ulayat lands shall have no legal protection at all. From many regions in Indonesia, only one province has recognized the presence of ulayat lands in its regional regulation, namely the Nagariland in West Sumatra.

Besides, this model does not ensure recognition from the central government. If the central government initiates its other interests upon such an area, it may issue a land certificate to other parties over the ulayat land. Hence, this scheme shall not be able to provide legal protection to the adat peoples fully.

It shall be an entirely different story if the legal protection is in the form of a land certificate. The land registration initiative shall be from the adat peoples; hence, the State shall have an obligation to issue the ulayat land certificate to the adat peoples upon fulfilling the requirements.

The grant of the ulayat land certificate to the adat peoples is a giant leap forward. Previously, the adat peoples in Indonesia have no means of legal certainty to defend their position. Better legal certainty will be produced if the land certificate is granted permanently.
It is worth noting that the grant of certificate to the adat peoples signifies a communal and collective registration; it shall not reflect individual interest. A grant of certificate to individual subjects within the adat community will open the possibility for such individuals to sell or put the land as security. It may be resulting in the loss of the adat peoples' rights.

Indonesia recognizes the presence of ulayat land at the fulfillment of particular requirements, namely the existence of an area where there are a group of adat peoples complying with specific customary law and the presence of a customary chief or administrator. The government may use these four requirements as the pre-requisite for land registration or the issuance of land certificates for the adat peoples. In case the relevant adat peoples ceased to exist or lost one or more requirements from the four conditions mentioned above, the government may revoke the land certificate.

The said mechanism does not only applied to the adat peoples; the government may revoke any type of unutilized or abandoned rights, including the right of ownership. Essentially, Indonesia's lands are considered as having a social function or must be actively used and not abandoned.

By granting a permanent land certificate to the adat peoples, the government has made a concrete step in protecting the adat peoples and showing the importance of their presence. The grant of the permanent/absolute land certificate is utterly possible and does not prohibit the laws. However, this is highly dependant on the government's political will, whether they want to protect the adat peoples or just considering them as a marginalized community without the need for legal protection. The grant of permanent land certificate to the adat peoples manifests the State's defense as mandated by the constitution.

\section{CONCLUSION}

As a civilized nation, it is a given that a country must provide exceptional protection and attention to the adat peoples. The legal protections may be manifested through granting a permanent land certificate, which utterly possible. However, it depends on the State's commitment and willingness to execute the constitution's mandate in protecting the adat peoples. Suppose the State has already possessed sufficient commitment and desire; in that case, it is only a matter of time for the adat peoples to obtain the permanent land certificate over the ulayat lands. Such 
implementation will require significant changes to Indonesia's land registration system, particularly by first shifting the negative land registration system into the positive registration system.

\section{REFERENCES}

Akuffo, K. (2009). The conception of land ownership in African customary law and its implications for development, African Journal of International and Comparative Law, 17(1), 57. https://doi.org/10.3366/E0954889009000280

Azmi, I. M. A. G. (2017). Voices from the dead: the uneasy case of indigenous cultural expression, International Journal of Law and Managemen, 59(4): 522-533. https://doi.org/10.1108/IJLMA-03-2016-0027

Butzier, S. R., \& Stevenson, S. M. (2014). Indigenous Peoples' Rights to Sacred Sites and Traditional Cultural Properties and the Role of Consultation and Free, Prior and Informed Consent, Journal of Energy \& Natural Resources Law, 32(8), No. 3.

https://doi.org/10.1080/02646811.2014.11435364

Charters, C. (2008). Indigenous Peoples' Land Rights under International Law: From Victims to Actors, International \& Comparative Law Quarterly, 57(2): 491-494. https://doi.org/10.1017/S0020589308000353

Corrin, J. (2014). Round pegs and square holes: pleading indigenous customary laws in Australia and the South Pacific, Civil Justice Quarterly, 33(4): 475-493.

Dalidjo, N. (2020). Wisdom on the Natural Resources Management in Kasepuhan Ciptagelar, http://perkumpulanskala.net/index. php/en/culture/163-kearifan-pengelolaan-sda-di-kasepuhanciptagelar

Deda, A. J., \& Mofu, S. S. (2014). Adat Peoples and the Ulayat Rights in West Papua Province as the Indigenous Peoples of Papua Reviewed from the Prespective of Customs and Culture: Recent Ethnographic Study, Journal of Public Administration, 1(1): 76-78.

Daulay, F. F. (2014). Nationalization of the Ulayat Land of the Kingdom of Deli is Considered as Wrong, https://medan. tribunnews.com/2014/02/04/abdul-hakim-nasionalisai-tanahulayat-kesultanan-deli-keliru

Forrest, C., \& Corrin, J. (2013). Legal pluralism in the Pacific: Solomon Island's World War II heritage, International Journal of Cultural Property, 20(1): 1-21. https://doi.org/10.1017/S0940739112000458

Gilbert, J. (2017). Litigating indigenous peoples' rights in Africa: potentials, challenges and limitations, International \& Comparative Law Quarterly, 66(3): 1-28.

Gunn, B. L. (2013). More than Money: Using International Law of Reparations to Determine Fair Compensation for Infringements of Aboriginal Title, UBC Law Review, 46, 299.

Grant, E. (2006). Human rights, cultural diversity, and customary law in South Africa, Journal of African Law, 50(1): 2-23. https://doi.org/10.1017/S0021855306000039

Hidayat, F. (2018). The Ulayat Land Dispute is Used by the Airport, More Productive Dialogue, https://www.wartaekonomi.co. id/read183445/sengketa-tanah-ulayat-dipakai-bandarabamsoet-dialog-lebih-produktif.htm

Hindeya, T. W. (2019). Indigeneity of peoples in the context of Ethiopia: a tool in the pursuit of justice against land dispossessions, African Journal of International and Comparative Law, 27(1): 1-24. https://doi.org/10.3366/ajicl.2019.0257

Eluyode, J. J. (2015). The blurred lines: analyzing the dynamics of states' duty and corporate responsibility to consult in developing countries, African Journal of International and Comparative Law, 23(3): 405-434.

https://doi.org/10.3366/ajicl.2015.0129

Waldron, J. J. (2003). Indigeneity? First Peoples and Last Occupancy, New Zealand Journal of Public and International Law, 1(1): 83-114.

Kawharu, A. (2015). Associate Professor in Law, The University of Auckland, The Values at Stake in the Screening of Foreign Investment in Land: A Legislative History in Three Acts, New Zealand Business Law Quarterly, 21, 235. https://dx.doi.org/10.2139/ssrn.2625295

Kalu, V. E. (2008). State Monopoly and Indigenous Participation Rights in Resource Development in Nigeria, Journal of Energy \& Natural Resources Law, 26(3): 418-449. https://doi.org/10.1080/02646811.2008.11435193

Kurniawan, (2017). This is the Trigger of the Ulayat Land Dispute in West Sumatra, https://kabar24.bisnis.com/read/20170418/ 78/646188/ini-pemicu-sengketa-tanah-ulayat-di-sumbar

Mclachlan, C. (1988). The recognition of Aboriginal customary law: pluralism beyond the colonial paradigm - a review article International \& Comparative Law Quarterly, 37(2): 368-386.

Nijar, G. S. (2013). Traditional Knowledge Systems, International Law And National Challenges: Marginalization Or Emancipation?, European Journal of International Law, 24, 1205-1221. https://doi.org/10.1093/ejil/cht077

Nyarko, M. G. (2019). The right to property and compulsory land acquisition in Ghana: a human rights perspective, African Journal of International and Comparative Law, 27(1): 100125. https://doi.org/10.3366/ajicl.2019.0261

Pereira, R., \& Gough, O. (2013). Permanent Sovereignty over Natural Resources in the $21^{\text {st }}$ Century: Natural Resource Governance and the Right to Self-Determination of Indigenous Peoples under International Law, Melbourne Journal of International Law, 14(2): 1-44.

Permana, R. H. (2019). Long History of Bloody Land Conflict in Mesuji, https://news.detik.com/berita/d-4629659/riwayatpanjang-konflik-tanah-berdarah-di-mesuji

Ramadhani, (2019). Two Thousand Hectares of Anak Dalam Tribe's Lands were Confiscated, https://www.gatra.com/detail/news/ 392526-Dua-Ribu-Hektar-Lahan-Suku-Anak-DalamDirampas-Perusahaan

Rifa'i, B. (2019) Traditional Baduy Leader Confessed, Demanding the Regional Government's Promise on the Ulayat Land, https://news.detik.com/berita/d-4537521/tokoh-adat-baduycurhat-tagih-janji-pemda-soal-tanah-ulayat

Sudantra, I. K. (2018). The Implication of the Decision of the Minister of Agraria and the Spatial Planning/Head of the National Land Agency 276/KEP-19.2/X/2017 Against the Position of the Land Owned by Pakraman Village, Udayana Magister Law Journal, Vol. 7 No. 4 (12): 546-564. https://doi.org/10.24843/JMHU.2018.v07.i04.p09

Sukoyo, Y. (2018). Adat Community of Megow Demands Settlement of their Land Rights, https://www.beritasatu.com/nasional/ 518451/masyarakat-adat-megow-pak-tuntut-penyelesaiantanah-hak-ulayat

Susyanthi, S. (2020). Analysis on the Existence of the Customary Land Law of the Dayak Kenyah Tribe in East Kalimantan, http://lib.ui.ac.id/file?file=digital/2016-12/20269964-T37505Siti\%20Susyanthi.pdf

Tamagola, T. A. (2016). Ulayat Rights and Customary Rights in Indonesia, https://brwa.or.id/news/read/267

Treasure, W. (2016). From Mabo to Obuasi: Mining, Heritage and Customary Law in Ghana and Western Australia, Journal of Energy \& Natural Resources Law, 34(2): 191-211. https://doi.org/10.1080/02646811.2016.1133986 
Vadilla, V. (2017). Juridical Analysis of the Ownership Rights Over the Ulayat Land of the Malay Deli Adat Peoples (Study on the Supreme Court Decision Number 2113 K/PDT/2013), http://repositori.usu.ac.id/bitstream/handle/123456789/6015/ 147011114.pdf?sequence $=1$ \&isAllowed $=y$

Watson, S. (1996). New Zealand: investment in the land - foreign investors, International Company and Commercial Law Review, 7(9): 169-172.
Wily, L. A. (2018). Compulsory acquisition as a constitutional matter: the case in Africa, Journal of African Law, 62(1): 77-103. https://doi.org/10.1017/S0021855318000050

Yasand, M., \& Firmansyah, T. (2019). Looking at the Roots of the Bloody Land Conflict, https://nasional.republika.co.id/berita/ puun5g377/menengok-akar-konflik-lahan-berdarah-di-mesuji

Received on 20-05-2021

Accepted on 14-07-2021

Published on 19-07-2021

https://doi.org/10.6000/1929-4409.2021.10.144

(C) 2021 Zamil et al.; Licensee Lifescience Global.

This is an open access article licensed under the terms of the Creative Commons Attribution Non-Commercial License (http://creativecommons.org/licenses/by-nc/3.0/) which permits unrestricted, non-commercial use, distribution and reproduction in any medium, provided the work is properly cited. 